\title{
ASSESSMENT OF VITAMIN D IN COLONIC DISEASES (INFLAMMATORY BOWEL DISEASES AND IRRITABLE BOWEL SYNDROME)
}

\author{
Hebatallah Ashraf Sallam ${ }^{1}$, Sameh Mohamed Ghaly ${ }^{2}$, Ashraf Elsherbiny Abdel \\ Hady Elsherbiny', Hesham Hamdy Radwan 2, Yasser Omar Eid'2, and \\ Ayman Gamil Dawod ${ }^{2}$
}

\begin{abstract}
${ }^{1}$ Department of Internal
Medicine , National Research

Center, ${ }^{2}$ Department of Internal

Medicine, Faculty of Medicine,

Ain Shams University, Cairo,

Egypt
\end{abstract}

\section{Corresponding author}

Hebatallah Ashraf Sallam

Mobile: (+2) 01002527282

E.mail:

hsallam1982@gmail.com

Received: $11 / 5 / 2021$

Accepted: 31/5/2021

\section{Online ISSN: 2735-3540}

\begin{abstract}
:
Background: Vitamin D is a steroid hormone that is produced as a result of skin exposure to the sunlight. Vitamin $D$ is essential to different organs and systems in the body as the bones, intestines, immune system, pancreas, brain, and control of cell cycle.
\end{abstract}

Aim of the work: to assess the clinical relevance of vitamin $D$ in colonic diseases (IBS and IBD) to know if there is a prevalence of vitamin $D$ deficiency in these colonic diseases.

Patients and Methods: This study was performed on 90 Egyptian patients who were classified into 3 groups; where Group 1 included 30 patients who have irritable bowel syndrome (IBS), Group 230 patients who have inflammatory bowel disease (IBD) whether Ulcerative Colitis (UC) or Crohn's Disease (CD) and Group 330 healthy personnel taken as Control group.

Results: Regarding different vitamin $D$ levels in the studied groups. In the control group, (20\%) had deficient vitamin D level (< $20 \mathrm{ng} / \mathrm{ml})$, (30\%) had insufficient vitamin D level $(20-30 \mathrm{ng} / \mathrm{ml})$, $(50 \%)$ had optimal vitamin D level (>30 $\mathrm{ng} / \mathrm{ml})$. In IBS group, (60\%) had deficient vitamin D level, $(26.7 \%)$ had insufficient vitamin D level, (13.3\%) had optimal vitamin D level. In the UC group, $(66.7 \%)$ had deficient vitamin D level, (16.7\%) had insufficient vitamin D level, (16.7\%) had optimal vitamin D level. In CD group, (50\%) had deficient vitamin D level, (33.3\%) had insufficient vitamin D level, (16.7\%) had optimal vitamin D level.

Conclusion: The role of vitamin D deficiency in the pathogenesis of many chronic illnesses has raised the attention recently. Our study revealed that 25-OH-D3 deficiency is found more frequently among $U C, C D$ and IBS patients than normal healthy controls. Thus, vitamin $D$ prescription in these patients may help in improving these colonic diseases.

Keywords: Inflammatory bowel diseases, irritable bowel syndrome.

\section{INTRODUCTION:}

Colonic diseases are one of the most irritable and annoyable diseases that affect the life style of the patients and their treatment cost the patients a lot with non- satisfactory results. Colonic diseases includes Irritable Bowel Syndrome (IBS) and Inflammatory Bowel Disease (IBD). ${ }^{(1)}$

Inflammatory Bowel Disease (IBD) is an idiopathic disease caused by a 
deregulated immune response to host intestinal microflora. The two major types of IBD are Ulcerative Colitis (UC), which is limited to the colon, and Crohn's Disease (CD), which can affect any segment of the gastrointestinal tract from the mouth to the anus. While Irritable Bowel syndrome (IBS) is a chronic gastrointestinal disorder marked by disorganized bowel function due to neurohormonal bowel wall-gut axis dysfunction. ${ }^{(1)}$

Irritable Bowel Syndrome and Inflammatory Bowel Disease can have similar symptoms, but IBS is less serious than IBD. IBS does not cause inflammation, intestinal bleeding, rectal bleeding, ulcers, permanent damage to the intestines, or complications that can occur with IBD ${ }^{(2)}$

Vitamin D has been found to be strongly associated with many systemic disorders. There has been an interest within the medical community in vitamin D deficiency in various systemic disorders. ${ }^{(3)}$

Although the role of vitamin D deficiency in IBS has not yet been determined, studies are underway to clearly establish its role in the disease. A recent report on the successful treatment of diarrhea predominant IBS with high doses of oral vitamin D supplementation-associated with the resolution of anxiety and depression as well-has raised interest from the scientific community in vitamin $D$ role in IBS. ${ }^{(4)}$

Low serum 25-hydroxyvitamin D levels have been repeatedly reported in IBD together with a possible relationship between vitamin $\mathrm{D}$ status and disease activity. Subsequently, low serum vitamin D levels have been reported in various immune-related diseases pointing to an immune regulatory role. Indeed, vitamin D and its receptor (VDR) are known to interact with different players of the immune homeostasis by controlling cell proliferation, antigen receptor signaling, and intestinal barrier function. ${ }^{(5)}$

\section{AIM OF THE WORK:}

The present work aimed to study the clinical relevance of vitamin $\mathrm{D}$ in colonic diseases (IBS and IBD) to know if there is a prevalence of vitamin $D$ deficiency in these colonic diseases.

\section{PATIENTS AND METHODS:}

It is an observational cross sectional study that was performed on 90 Egyptian patients taken from the IBDMDT clinic (Inflammatory Bowel Disease MultiDisciplinary Team Clinic) and Inpatient Department of Ain Shams University Hospital during the period from November 2017 till November 2019 after approval of Ethical Committee and an informed consent was taken from the patients.

The subjects were classified into three groups: Group 1 included: 30 patients who have irritable bowel syndrome diagnosed by Rome IV criteria ${ }^{(6)}$, Group 2 included: 30 patients who have inflammatory bowel disease whether Ulcerative Colitis or Crohn's Disease diagnosed as IBD by colonoscopy and histopathology and Group 3 included: 30 patients who were healthy personnel taken as control group.

Patients with the following Criteria were excluded from the study, pregnant or lactating females, an established diagnosis of any concomitant bowel disturbance that would interfere with the assessment of efficacy or safety in the study (e.g. cancer colon, celiac disease), have a history of significant concomitant diseases as (hepatic, renal diseases) that may affect the level of vitamin $\mathrm{D}$, active laxative abuse or currently taking Vitamin D supplements.

Full history was taken from all individuals included in this study with a 
thorough clinical examination. All participants in this study were subjected to routine laboratory investigations including Complete Blood Count, Albumin, INR, Total and Direct bilirubin, ALT, AST, and Alkaline Phosphatase, Serum Creatinine and Blood Urea, Fasting Blood Sugar and HbA1C. Measurement of serum vitamin D level using ELISA assay for all subjects. Serum vitamin D was measured by Enzyme Linked Immunosorbent assay (ELISA) using Human MDA ELISA KIT by Glory Science Co., Ltd 2400 Veterans Blvd. Suite 16 - 101, Del Rio, TX 78840, USA.

\section{Statistical methods:}

Statistical presentation and analysis of the present study was conducted, using the mean, standard deviation, student t- test, Paired t-test, Chi-square by SPSS V20. Significance level (P) value was expressed as follows: $\mathrm{P}>0.05$ : Insignificant. $\mathrm{P}<0.05$ : Significant. $\mathrm{P}<0.01$ : Highly significant.

\section{RESULTS:}

This study included 90 patients who were divided into three groups; Group 1: 30 patients with IBS, Group 2: 30 patients with IBD whether Ulcerative Colitis or Crohn's Disease, and Group 3: 30 healthy subjects.

Table (1): Comparison between the studied groups according to Gender.

\begin{tabular}{|l|l|l|l|l|}
\hline \multirow{2}{*}{ Groups } & Gender & Total & \multirow{2}{*}{ P } \\
\cline { 2 - 3 } & Male & Female & & \multirow{2}{*}{0.96} \\
\hline Control & $14(46 \%)$ & $16(54 \%)$ & 30 & \\
\hline IBS & $16(54 \%)$ & $14(46 \%)$ & 30 & \\
\hline UC & $9(37.5 \%)$ & $15(62.5 \%)$ & 24 & \\
\hline Crohn's & $4(66.5 \%)$ & $2(33.5 \%)$ & 6 & \\
\hline Total & 30 & 60 & 90 & \\
\hline
\end{tabular}

Table (1) showed that regarding gender distribution, IBS group included 16 males $(54 \%)$ and 14 females $(46 \%)$. In the Ulcerative colitis group, there were 9 males
(37.5\%) and 15 females $(62.5 \%)$ while in Crohn's Disease group, there were 4 males $(66.5 \%)$ and 2 females $(33.5 \%)$ and these results were not statistically significant.

Table (2): BMI among different study population

\begin{tabular}{|l|c|c|c|}
\hline Groups & Mean & Std. Deviation & P value \\
\hline Control $(\mathrm{n}=30)$ & 30.6 & 2.1 & \multirow{2}{*}{.008} \\
\cline { 1 - 2 } IBS $(\mathrm{n}=30)$ & 23.4 & 3.0 & \\
\cline { 1 - 2 } Ulcerative colitis $(\mathrm{n}=24)$ & 22.6 & 2.7 & \\
\hline Crohn`s Disease $(\mathrm{n}=6)$ & 22.4 & 2.9 & \\
\hline
\end{tabular}

Table (2) shows regarding the BMI among different study populations, there was a high statistical significant difference between the groups, where the BMI of the
Control group $(30.6 \pm 2.1 \mathrm{SD})$, IBS group $(23.4 \pm 3)$, UC group $(22.6 \pm 2.7)$ and the CD group $(22.4 \pm 2.9)$.

Table (3): CRP level among different study population

\begin{tabular}{|l|c|c|c|}
\hline Groups & Mean & Std. Deviation & \multirow{2}{*}{ P value } \\
\hline Control $(\mathrm{n}=30)$ & 2.97 & 3.21 & \multirow{2}{*}{.000} \\
\hline IBS $(\mathrm{n}=30)$ & 2.83 & 1.34 & \\
\hline Ulcerative colitis $(\mathrm{n}=24)$ & 9.79 & 5.49 & \\
\hline Crohn`s Disease $(\mathrm{n}=6)$ & 9.67 & 6.40 & \\
\hline
\end{tabular}


Table (3) shows that regarding the CRP mean level, there was a high statistical significant difference between the groups, where the CRP mean level of the control group $(2.97 \pm 3.21 \mathrm{SD})$, IBS group $(2.83 \pm$ 1.34) and both were lower than that of the UC group $(9.79 \pm 5.49)$ and the CD group $(9.67 \pm 6.40)$ with $\mathrm{p}$ value of $<0.01$

Table (4): CRP cutoff level among different study population

\begin{tabular}{|l|c|c|c|c|}
\hline \multirow{2}{*}{ Groups } & \multicolumn{2}{|c|}{ CRP cutoff } & \multirow{2}{*}{ Total } & P \\
& value \\
\hline Control & CRP $>5$ & CRP $<5$ & & \\
\hline IBS & $1(3.3 \%)$ & $29(96.7 \%)$ & 30 & \\
\hline Ulcerative Colitis & $2(6.6 \%)$ & $28(93.4 \%)$ & 30 & \multirow{2}{*}{0.009} \\
\hline Crohn's Disease & $8(33.3 \%)$ & $16(66.7 \%)$ & 24 & \\
\hline Total & $1(16.6 \%)$ & $5(83.4 \%)$ & 6 & \\
\hline
\end{tabular}

Table (4) shows most of the enrolled candidates were having a CRP cutoff level $(<5 \mathrm{mg} / \mathrm{l}) 78$ cases $(86.6 \%)$ in comparing to
12 cases $(13.4 \%)$ whose CRP cutoff level was $(>5 \mathrm{mg} / \mathrm{l})$ and this difference was statistically significant with $p$ value $<0.05$

\section{CRP level in different study population}

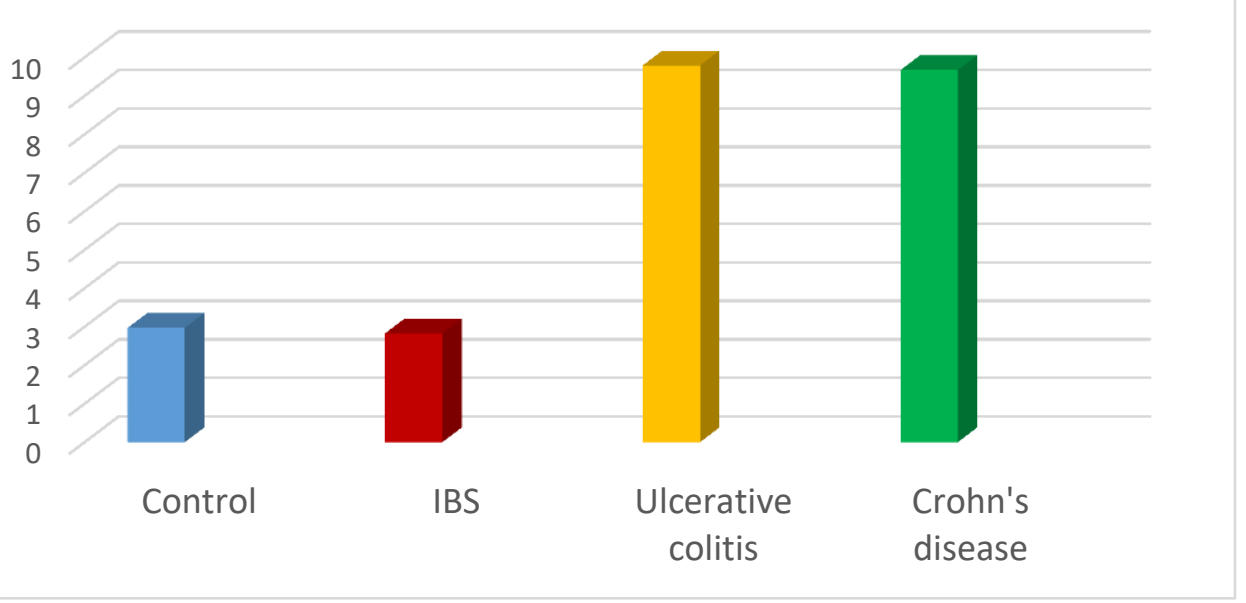

Figure (1): Column chart comparing CRP levels among different study population

Table (5): Fecal calprotectin level among different study population

\begin{tabular}{|l|c|c|c|}
\hline Groups & Mean & Std. Deviation & P value \\
\hline Control $(\mathrm{n}=30)$ & 12.76 & 7.51 & \multirow{2}{*}{.000} \\
\hline IBS $(\mathrm{n}=30)$ & 14.57 & 7.31 & 57.34 \\
\hline Ulcerative colitis $(\mathrm{n}=24)$ & 107.29 & 73.68 & \\
\hline Crohn`s Disease $(\mathrm{n}=6)$ & 110.83 & 0 \\
\hline
\end{tabular}

Table (5) shows that regarding the Fecal calprotectin mean level, there was a high statistical significant difference between the groups, where the Fecal calprotectin mean level of the control group (12.76 $\pm 7.51 \mathrm{SD})$, IBS group (14.57 \pm 7.31$)$ and both were lower than that of the UC group (107.29 \pm $57.34)$ and the CD group (110.83 \pm 73.68$)$. 
Assessment Of Vitamin D In Colonic Diseases (Inflammatory Bowel Diseases and Irritable ..

Table (6): Fecal calprotectin cutoff level among different study population

\begin{tabular}{|l|c|c|c|c|}
\hline \multirow{2}{*}{ Groups } & \multicolumn{2}{|c|}{ Fecal Calprotectin cut off } & Total & \multirow{2}{*}{$\begin{array}{c}\text { P } \\
\text { value }\end{array}$} \\
\cline { 2 - 4 } & FC $>100$ & FC $<100$ & & \multirow{2}{*}{0.000} \\
\hline Control & $0(0 \%)$ & $30(100 \%)$ & 30 & \\
\hline IBS & $0(0 \%)$ & $30(100 \%)$ & 30 & \\
\hline Crohn's Disease & $5(20.8 \%)$ & $19(79.2 \%)$ & 24 & \\
\hline Total & $1(16.6 \%)$ & $5(83.4 \%)$ & 6 & \\
\hline
\end{tabular}

Table (6) shows that Most of the enrolled candidates were having a Fecal calprotectin cutoff level $(<100 \mu \mathrm{g} / \mathrm{mg}) 84$ cases $(93.3 \%)$ in comparing to 6 cases
(6.7\%) whose Fecal calprotectin cutoff level was $(>100 \mu \mathrm{g} / \mathrm{mg})$ and this difference was statistically significant with $\mathrm{p}$ value $<0.001$

\section{Fecal calprotectin level in different study population}

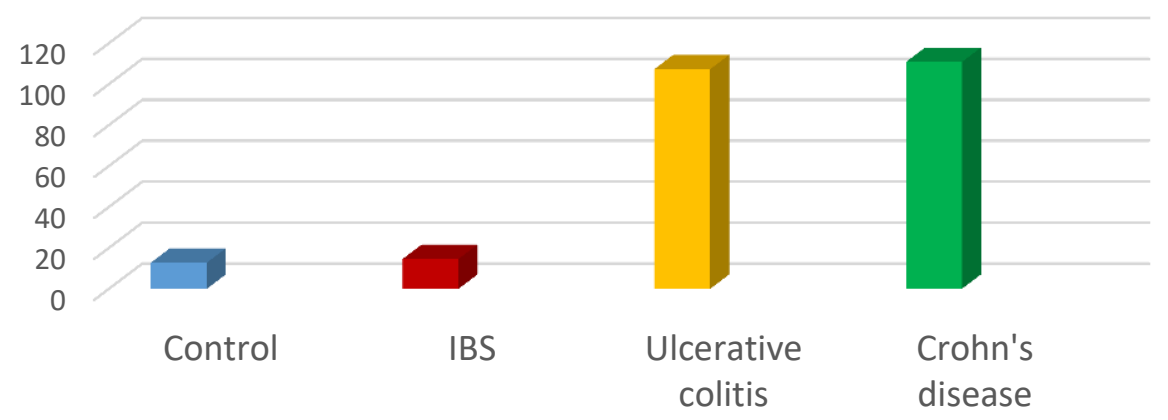

Figure (2): Column chart comparing fecal calprotectin level among different study population Table (7): Comparison between control and cases as regards vitamin D level.

\begin{tabular}{|l|l|c|c|c|}
\hline \multicolumn{2}{|l|}{ Variable } & \multicolumn{2}{|c|}{ Groups } & T-test \\
\cline { 3 - 5 } \multicolumn{2}{|c|}{} & $\begin{array}{c}\text { Control } \\
(\mathrm{n}=30)\end{array}$ & $\begin{array}{c}\text { Cases } \\
(\mathrm{n}=60)\end{array}$ & P-value \\
\hline \multirow{2}{*}{ Vitamin D level } & Range & $10-70$ & $4-30$ & 0.000 \\
\cline { 2 - 5 } & Mean \pm SD & $29 \pm 7$ & $12 \pm 6.9$ & \\
\hline
\end{tabular}

Table (7) shows that The mean level of vitamin $\mathrm{D}$ in case group was significantly low measuring $12 \mathrm{ng} / \mathrm{ml} \pm 6.9 \mathrm{SD}$ compared to a higher level among control group (29 $\mathrm{ng} / \mathrm{ml} \pm 7 \mathrm{SD}$ ) and this was statistically highly significant with $\mathrm{p}$ value $<0.01$

Table (8): Vitamin D mean levels among different study population

\begin{tabular}{|l|c|c|c|}
\hline Groups & Mean & Std. Deviation & P value \\
\hline Control $(\mathrm{n}=30)$ & 29.0667 & 7.07576 & \multirow{2}{*}{.000} \\
\cline { 1 - 2 } IBS $(\mathrm{n}=30)$ & 11.9667 & 6.66169 & \\
\hline Ulcerative colitis $(\mathrm{n}=24)$ & 11.6667 & 7.19702 & \\
\cline { 1 - 2 } Crohn`s Disease $(\mathrm{n}=6)$ & 15.3333 & 8.01665 & \\
\hline
\end{tabular}


Table (8)shows that regarding the vitamin $\mathrm{D}$ mean level, there was a high statistical significant difference between the groups, where the vitamin D mean level of the control group $(29.06 \pm 7.07 \mathrm{SD})$ which was higher than that of IBS group (11.96 \pm $6.66)$, the UC group $(11.66 \pm 7.19)$ and the $\mathrm{CD}$ group $(15.33 \pm 8.01)$ with $\mathrm{p}$ value of $<0.01$.

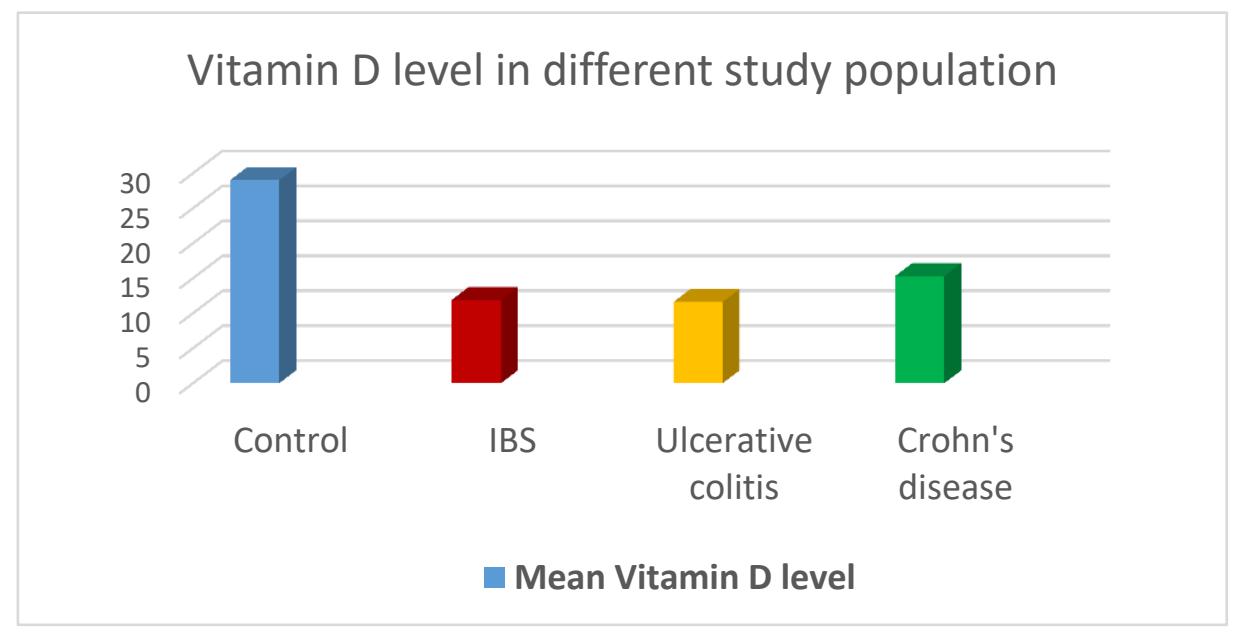

Figure (3): Column chart comparing vitamin D levels among different study population

Table (9): Vitamin D levels in different groups regarding its sufficiency

\begin{tabular}{|l|c|c|c|}
\hline \multirow{2}{*}{ Groups } & \multicolumn{3}{|c|}{ Vitamin D level } \\
\cline { 2 - 4 } & $\begin{array}{c}\text { Deficient } \\
(<20 \mathrm{ng} / \mathrm{ml})\end{array}$ & $\begin{array}{c}\text { Insufficient } \\
(20-30 \mathrm{ng} / \mathrm{ml})\end{array}$ & $\begin{array}{c}\text { Optimal } \\
(>30 \mathrm{ng} / \mathrm{ml})\end{array}$ \\
\hline Control $(\mathrm{n}=30)$ & $6(20 \%)$ & $9(30 \%)$ & $15(50 \%)$ \\
\hline IBS(n=30) & $18(60 \%)$ & $8(26.7 \%)$ & $4(13.3 \%)$ \\
\hline Ulcerative Colitis $(\mathrm{n}=24)$ & $16(66.7 \%)$ & $4(16.7 \%)$ & $4(16.7 \%)$ \\
\hline Crohn's Disease $(\mathrm{n}=6)$ & $3(50 \%)$ & $2(33.3 \%)$ & $1(16.7 \%)$ \\
\hline
\end{tabular}

Table (9) shows different vitamin D levels in the studied groups. In the control group, 6 patients (20\%) had deficient vitamin $\mathrm{D}$ level $(<20 \mathrm{ng} / \mathrm{ml}), 9$ patients $(30 \%)$ had insufficient vitamin D level (20 $30 \mathrm{ng} / \mathrm{ml}), 15$ patients $(50 \%)$ had optimal vitamin D level (>30ng/ml). In IBS group, 18 patients $(60 \%)$ had deficient level, 8 patients (26.7\%) had insufficient level, 4 patients $(13.3 \%)$ had optimal level. In the UC group, 16 patients (66.7\%) had deficient level, 4 patients $(16.7 \%)$ had insufficient level, 4 patients $(16.7 \%)$ had optimal level. In CD group, 3 patients (50\%) had deficient level, 2 patients $(33.3 \%)$ had insufficient level, 1 patient $(16.7 \%)$ had optimal level. 
Assessment Of Vitamin D In Colonic Diseases (Inflammatory Bowel Diseases and Irritable ..

Table (10): Correlations between Vitamin D levels, CRP and Fecal calprotectin

\begin{tabular}{|c|c|c|c|c|}
\hline \multicolumn{3}{|l|}{ Groups } & CRP & fecal calprotectin \\
\hline \multirow[t]{2}{*}{ IBS } & \multirow{8}{*}{ Vitamin D level } & $\begin{array}{l}\text { Correlation } \\
\text { Coefficient }\end{array}$ & -.020 & -.065 \\
\hline & & $\mathrm{P}$ value & .917 & .734 \\
\hline \multirow[t]{2}{*}{ Ulcerative Colitis } & & $\begin{array}{l}\text { Correlation } \\
\text { Coefficient }\end{array}$ & -.282 & -.164 \\
\hline & & $\mathrm{P}$ value & .181 & .445 \\
\hline \multirow[t]{2}{*}{ Crohn's Disease } & & $\begin{array}{l}\text { Correlation } \\
\text { Coefficient }\end{array}$ & .225 & .070 \\
\hline & & $\mathrm{P}$ value & .669 & .895 \\
\hline \multirow[t]{2}{*}{ Control } & & $\begin{array}{l}\text { Correlation } \\
\text { Coefficient }\end{array}$ & -.043 & -.196 \\
\hline & & $\mathrm{P}$ value & .820 & .298 \\
\hline
\end{tabular}

Table (10) shows that on assessing the correlation between vitamin D levels and CRP values among different groups, there were only non-significant weak correlations observed. Similarly there was no significant correlation between vitamin D levels and fecal calprotectin levels.

\section{DISCUSSION:}

Vitamin D is a fat-soluble vitamin that is produced by exposing the skin to the ultraviolet rays of sunlight. Then, it undergoes two hydroxylations in the body for activation. The first occurs in the liver and converts vitamin $\mathrm{D}$ to 25hydroxyvitamin D [25(OH) D], also known as calcidiol. The second occurs primarily in the kidney and forms the physiologically active 1,25-dihydroxyvitamin $\mathrm{D}\left[1,25(\mathrm{OH})_{2}\right.$ D], also known as calcitriol ${ }^{(7)}$

A potential link between vitamin D deficiency and the occurrence of Irritable Bowel Syndrome is under research recently. As it is studied that the gut, being rich in microbiota, acts as a perfect site for the immune system activation, potentiating the effect of type-1 T helper cells and therefore, maintaining hemostasis. In this context, it has to be noted that vitamin D inhibits T-cell proliferation and so capable of inhibiting the immune response. ${ }^{(1)}$
Vitamin D has extra-skeletal activities like an immunomodulator, in particular its potent anti-inflammatory effects. As a consequence, vitamin D deficiency has been associated with many inflammatory diseases including Inflammatory Bowel Disease (IBD). ${ }^{()^{\circ}}$

Thus, the aim of this study was to assess the clinical relevance of vitamin $D$ in colonic diseases (IBS and IBD) to know if there is a prevalence of vitamin D deficiency in these colonic diseases.

This study was performed on 90 Egyptian patients who were classified into 3 groups; where Group 1 included 30 patients who have Irritable Bowel Syndrome (IBS) diagnosed by ROME IV criteria ${ }^{(6)}$, Group 2 included 30 patients who have Inflammatory Bowel Disease (IBD) whether Ulcerative colitis (UC) or Crohn's disease (CD) diagnosed as IBD by colonoscopy and histopathology and Group 3 included 30 patients who are healthy personnel taken as Control group.

In our study, regarding gender difference, gender distribution in the IBS group included 16 males $(54 \%)$ and 14 females $(46 \%)$. This result goes against the studies done by Daryani et al, 2012 ${ }^{(9)}$ and Caviezel et al., $2017^{(10)}$ who found that IBS is more common in females. 
On the contrary, females were more common than the males in the UC group, with 15 females $(62.5 \%)$ and 9 males $(37.5 \%)$ while in $\mathrm{CD}$ group, males were more common with 4 males $(66.5 \%)$ and 2 females $(33.5 \%)$ which goes with Caviezel et al., $2017^{(10)}$ study that showed also that males were more common in CD group 55 males $(51.5 \%)$ and 48 females $(48.5 \%)$ while females were more common in UC group 31 females $(54.4 \%)$ and 26 males $(45.6 \%)$.

IBD is more common in women in Western countries, especially CD patients (11). Our study results were similar to Matsuoka et al, $2018^{(11)}$. Nevertheless, in our study males were more common in Crohn's disease and this could be explained by the small number of patients (6 patients).

The use of oral contraceptives is associated with the development of IBD. Additionally, the use of non-steroidal antiinflammatory drugs (NSAIDs) is associated with the development and worsening of IBD which could explain why the IBD is more common in females ${ }^{(11)}$.

According to the study of Caviezel et al., $2017^{(10)}$ that was done on 181 patients (99 were diagnosed with $\mathrm{CD}, 57$ with UC, and 25 with IBS), there was no significantly difference in BMI of their patients, while in our study there was a statistically significant difference between control group with a BMI of $30.6 \pm 2.1 \mathrm{SD}$ which was higher than the BMI among the case group collectively $(24.2 \pm 3.1)$.

Blood-based biomarkers, such as Creactive protein (CRP) and fecal calprotectin are often used in helping IBD diagnosis, although, they have a low sensitivity, it was noted that at least $50 \%$ of patients with active ulcerative colitis (UC) had a normal CRP level. Additionally, CRP had a limited specificity, especially in patients with infections, or rheumatoid or other autoimmune disorders. Elevated fecal calprotectin levels have showed a significantly better correlation with activity of the disease in comparison to elevated CRP level ${ }^{(12)}$

Regarding the mean CRP level in our study, there was a high statistical significant difference between the groups, where the CRP mean level of the Control group (2.97 $\pm 3.21 \mathrm{SD})$, IBS group (2.83 \pm 1.34$)$ and both were lower than that of the UC group (9.79 $\pm 5.49)$ and the CD group $(9.67 \pm 6.40)$.

In our study, we used CRP > 5mg/l cutoff level as a marker in disease activity, as a result, $8(33.3 \%)$ patients with UC, 1 (16.6\%) patient with CD had CRP > 5mg/l while $16(66.7 \%)$ patients with UC, 5 (83.4\%) patients with CD had CRP $<5 \mathrm{mg} / 1$. The high levels of the CRP that appeared in the results of some patients may be explained by, part of our enrolled candidates were admitted at hospital due to the clinical exacerbation of the disease.

While in Caviezel et al., $2017^{(10)}$ study, the mean CRP level was $1.7 \mathrm{mg} / \mathrm{L}$ for CD patients and $1.5 \mathrm{mg} / \mathrm{L}$ for UC patients. Only $24.2 \%$ of CD patients and $19.3 \%$ of UC patients had a CRP level $>5 \mathrm{mg} / \mathrm{L}$. This was explained in their study that most of their patients with $\mathrm{CD}$ and $\mathrm{UC}$ were in clinical remission.

Regarding fecal calprotectin (FC) levels in IBD patients, when they are $50 \mu \mathrm{g} / \mathrm{g}$ to $100 \mu \mathrm{g} / \mathrm{g}$, quiescent disease is likely and therapy should be continued. If FC levels are $>100 \mu \mathrm{g} / \mathrm{g}$ to $250 \mu \mathrm{g} / \mathrm{g}$, inflammation is possible and further testing (eg, colonoscopy) is essential to confirm inflammation. While if FC levels are $>250 \mu \mathrm{g} / \mathrm{g}$, active inflammation is likely and strategies to control inflammation should be initiated (eg, optimizing current therapies or switching to an alternative therapy) ${ }^{(13)}$

Concerning the Fecal calprotectin (FC) mean level in our study, there was a high statistical significant difference between the groups, where the Fecal calprotectin mean 
level of the Control group $(12.76 \pm 7.51$ SD), IBS group (14.57 \pm 7.31) and both were lower than that of the UC group (107.29 \pm 57.34) and the CD group (110.83 \pm 73.68$)$.

The FC cutoff level in our study showed that $5(20.8 \%)$ patients with UC, $1(16.6 \%)$ patient with $\mathrm{CD}$ had $\mathrm{FC}>100 \mu \mathrm{g} / \mathrm{g}$ while 19 (79.2\%) patients with UC, 5 (83.4\%) patients with $\mathrm{CD}$ had $\mathrm{FC}<100 \mu \mathrm{g} / \mathrm{g}$.

This result goes against Caviezel et al., $2017^{(10)}$, in their study the found that approximately $60 \%$ of CD and UC patients had an FC level $>100 \mu \mathrm{g} / \mathrm{g}$ stool at the time of analysis which is much higher than our results.

Regarding the mean level of vitamin D in our study, there was a high statistical significant difference between the groups, where the vitamin $\mathrm{D}$ mean level of the control group $(29.06 \pm 7.07 \mathrm{ng} / \mathrm{mL})$ which was higher than that of IBS group (11.96 $6.66 \mathrm{ng} / \mathrm{mL}$ ). This goes with Cho et al, 2018 (14) study that showed that the mean 25-OHD level in IBS patients was low with a value of $(16.25 \pm 6.58 \mathrm{ng} / \mathrm{mL})$. They found that the average vitamin $\mathrm{D}$ level of the IBS-D patients $(15.25 \pm 7.25 \mathrm{ng} / \mathrm{mL})$ was lower than that of the other types $(18.47 \pm 7.37 \mathrm{ng} / \mathrm{mL}$ in IBS-C, $16.22 \pm 3.29 \mathrm{ng} / \mathrm{mL}$ in IBS-M), but the difference was not statistically significant.

Also, our results goes with Khayyat and Attar, $2015^{(1)}$ study that revealed these statistically significant results; Firstly, the mean serum level of $25(\mathrm{OH}) \mathrm{D}$ in IBS patients was $8.4 \pm 4.8 \mathrm{ng} / \mathrm{ml}$ compared to the control group $12.4 \pm 6.4 \mathrm{ng} / \mathrm{ml}$, Secondly, the frequency of vitamin $\mathrm{D}$ deficiency was found to be high in the IBS group $(82 \%)$.Vitamin D deficiency was detected in 49 patients $(82 \%)$ in the IBS group and 31 patients $(31 \%)$ in the control group in their study. There was a statistically significant difference in the mean vitamin D level between the IBS group and control group.
In IBD patients, serum level of vitamin $\mathrm{D}$ was significantly reduced, particularly in the winter and spring times where UVinduced synthesis of vitamin D is decreased. In addition, the intestinal malabsorption which is associated with IBD contributes to the reduced serum $25(\mathrm{OH}) \mathrm{D}$ in IBD patients $^{(8)}$.

According to Zhao et al. 2019 ${ }^{(15)}$, the serum vitamin D levels in the UC (10.27 \pm $4.05 \mathrm{ng} / \mathrm{mL})$ and CD $(11.13 \pm 3.96 \mathrm{ng} / \mathrm{mL})$ groups were lower than in the control group $(12.96 \pm 5.18 \mathrm{ng} / \mathrm{mL})$ indicating that patients with IBD have lower levels of vitamin D than healthy individuals. This goes with our study that showed that the vitamin D level of the control group $(29.06 \pm 7.07 \mathrm{ng} / \mathrm{ml})$ which was higher than that of the UC group (11.66 $\pm 7.19 \mathrm{ng} / \mathrm{ml})$ and the CD group (15.33 \pm $8.01 \mathrm{ng} / \mathrm{ml})$.

Concerning our study, patients in the Ulcerative Colitis group had a vitamin D level range between 4 and $30 \mathrm{ng} / \mathrm{mL}$ with a mean of $(11.6 \pm 7.1 \mathrm{ng} / \mathrm{ml})$ while in the Crohn's Disease group, the range was between 6 and $30 \mathrm{ng} / \mathrm{mL}$ with a mean of $(15.3 \pm 8 \mathrm{ng} / \mathrm{ml})$ and So there was no statistically significant difference between the two groups. This result goes with Schäffler et al., $2018^{(16)}$ that showed that there was no significant difference in the vitamin D levels between the CD $(22.5 \pm$ $8.25 \mathrm{ng} / \mathrm{ml}, \mathrm{n}=123)$ and UC groups $(23.8 \pm$ $9.1 \mathrm{ng} / \mathrm{ml}, \mathrm{n}=85$ )

The benefits of vitamin $D$ supplementation to IBD patients are still debatable. Whether improved vitamin D status may help to prevent the onset of IBD as well as ameliorating disease severity is true is still questionable. Some pre-clinical studies, notably with mouse models, demonstrated the advantages of vitamin D supplementation in IBD as the active form of vitamin $\mathrm{D}$, 1,25-dihydroxyvitamin $\mathrm{D}$ $(1,25-(\mathrm{OH}) 2 \mathrm{D})$ has been shown to promote the intestinal micro flora functions, and 
consequently improve anti-inflammatory and tolerogenic immune responses. ${ }^{(8)}$

A study done by Caviezel et al., $2017^{(10)}$, showed that vitamin D mean levels were decreased in the patients with CD (13.6 $\pm 25.4 \mathrm{ng} / \mathrm{ml})$ and UC $(14.2 \pm 27.7 \mathrm{ng} / \mathrm{ml})$ when compared to the IBS patients (18.8 \pm $31.2 \mathrm{ng} / \mathrm{ml}$ ). This was against our study that showed vitamin D mean levels were decreased in the patients with IBS (11.96 \pm $6.66 \mathrm{ng} / \mathrm{ml})$ and UC $(11.66 \pm 7.19 \mathrm{ng} / \mathrm{ml})$ when compared to the CD patients $(15.33 \pm$ $8.01 \mathrm{ng} / \mathrm{ml})$.

Regarding Castro et al, $2015^{(17)}$, where a total of 76 patients were enrolled, 19 with ulcerative colitis (25\%) and 57 with Crohn's disease $(75 \%)$. Overall, mean serum 25 hydroxyvitamin D levels were low (26.0 \pm $10.0 \mathrm{ng} / \mathrm{mL}$ ), while those in patients with Crohn's disease were significantly lower than ulcerative colitis $(24.6 \pm 8.0$ vs $30.0 \pm$ $12.5 \mathrm{ng} / \mathrm{mL}$ ). Vitamin $\mathrm{D}$ deficiency was found in $30 \%$ of patients. While in our study, although the mean serum 25 hydroxyvitamin D levels were also low (12 $\pm 6.9 \mathrm{ng} / \mathrm{ml}$ ) but the patients with ulcerative colitis disease were significantly lower than Crohn's disease. $(11.66 \pm 7.19$ vs15.33 \pm $8.01 \mathrm{ng} / \mathrm{ml}$ ). Again, this could be due to a lower number of Crohn's Disease patients in our study.

The evaluation of $25(\mathrm{OH}) \quad \mathrm{D}$ concentrations was performed and defined $25(\mathrm{OH})$ Vitamin D serum concentrations as normal (> $30 \mathrm{ng} / \mathrm{ml}$ ), insufficient (between 20 and $30 \mathrm{ng} / \mathrm{ml})$ or deficient $(<20$ $\mathrm{ng} / \mathrm{ml}){ }^{(18)}$

Regarding vitamin D level classification in our study, in IBS group, 18 patients (60\%) had deficient vitamin D level (< $20 \mathrm{ng} / \mathrm{ml}), 8$ patients $(26.7 \%)$ had insufficient vitamin D level $(20-30 \mathrm{ng} / \mathrm{ml}), 4$ patients (13.3\%) had optimal vitamin D level $(>30 \mathrm{ng} / \mathrm{ml})$. However, in the study of Abbasnezhad et al. 2016 ${ }^{(19)}$, the percentage of patients who had serum $25(\mathrm{OH})$
$\mathrm{D}_{3}$ concentrations below 30ng/mL, and over $30 \mathrm{ng} / \mathrm{ml}$ was $84.1 \%$, and $15.9 \%$ respectively.

While in our study, the UC group, 16 patients $(66.7 \%)$ had deficient vitamin D level $(<20 \mathrm{ng} / \mathrm{ml}), 4$ patients $(16.7 \%)$ had insufficient vitamin D level (20-30 ng/ml), 4 patients $(16.7 \%)$ had optimal vitamin D level (>30 ng/ml). In CD group, 3 patients $(50 \%)$ had deficient vitamin D level $(<20$ $\mathrm{ng} / \mathrm{ml}), 2$ patients $(33.3 \%)$ had insufficient vitamin D level $(20-30 \mathrm{ng} / \mathrm{ml}), 1$ patient (16.7\%) had optimal vitamin D level (>30 $\mathrm{ng} / \mathrm{ml})$.

According to a study done by Branco et al $2019^{(20)}$, a total of 152 patients $(52 \%$ men; $47.2 \pm 17.3$ years) were included, of whom $70 \%$ had Crohn's disease (CD). Mean 25-OH-D levels were $17.1 \pm 8 \mathrm{ng} / \mathrm{mL}(\mathrm{CD}$ : $16.7 \pm 8 \mathrm{ng} / \mathrm{mL}$ vs. ulcerative colitis: $17.6 \pm$ $7 \mathrm{ng} / \mathrm{mL}$ ). Inadequate levels were present in $90.8 \%$ of patients. In UC group patients, $65 \%$ of patients had deficient vitamin D level, $28 \%$ of patients had insufficient vitamin $\mathrm{D}$ while in $\mathrm{CD}, 72 \%$ of patients had deficient vitamin D level, $20 \%$ of patients had insufficient vitamin $\mathrm{D}$ and their Conclusions were that there is a high prevalence of inadequate levels of vitamin $D$ in IBD patients, particularly deficiency $(68.4 \%)$. There seems to exist an association between lower levels of vitamin D and higher disease activity, especially in CD.

In our study, on assessing the correlation between vitamin D levels and CRP values among different groups (IBS, $\mathrm{CD}$ and $\mathrm{UC}$ ) there were only non-significant weak correlations observed. Also, there was no significant correlation between vitamin D levels and fecal calprotectin levels.

In contrast to our study, Caviezel et al., $2017^{(10)}$ study, linear regression analysis demonstrated that serum 25-OH-D3 levels were significantly inversely correlated with FC levels in CD patients and Similar to FC levels, CRP levels were significantly 
inversely correlated with serum 25-OH-D3. The differentiation between inflammation $(>5 \mathrm{mg} / \mathrm{L})$ and no inflammation $(\leq 5 \mathrm{mg} / \mathrm{L})$ was not associated with significant differences for CD patients.

However, in Caviezel et al., $2017^{(10)}$, no correlation was found between neither FC and 25-OH-D3 levels which was similar to our results nor CRP and 25-OH-D3 levels in UC patients.

However, in López-Muñoz et al, 2019 ${ }^{(21)}$ study, nonparametric linear correlation study of vitamin D with FC and CRP was performed. When two groups of patients were considered, both CD and UC showed a significant negative correlation between vitamin $\mathrm{D}$ and FC. In contrast to our study, we found non-significant correlation between vitamin D and FC in UC and $\mathrm{CD}$ patients.

Also in their study, López-Muñoz et al, 2019 ${ }^{(21)}$ demonstrates a strong correlation between CRP and vitamin D exclusively in patients with UC, not in CD. Again, this goes against our results as we found nonsignificant weak negative correlation between vitamin D and CRP in both UC and CD patients.

In contrast to our study, Branco et al 2019 (20) showed a significant negative correlation between 25-OH-D levels and Creactive protein (CRP) levels. Patients with severe deficiency showed a higher CRP (0.6 vs. $1.4 \mathrm{mg} / \mathrm{dl}$ ) while there was no association between vitamin D deficiency and fecal calprotectin.

In the evaluation of biochemical tests of Lorenzo et al, 2018 study $^{(22)}$, they observed that $63 \%(n=38)$ of the UC and CD patients presented high result for fecal calprotectin, $22 \%(n=13)$ had an indeterminate result, and $15 \%(n=9)$ were normal. For CRP, $87 \%(n=52)$ of the UC and CD patients had normal values and $13 \%(n=8)$ were above the reference level Establishing an inverse significant correlation between vitamin D and fecal calprotectin values and also between vitamin D and CRP values.

\section{Conclusion:}

The role of vitamin D deficiency in the pathogenesis of many chronic illnesses has raised the attention recently. This study revealed that 25-OH-D3 deficiency is found more frequently among UC, CD and IBS patients than normal healthy controls. This could raise a question whether vitamin $D$ supplementation in IBS and IBD patients would have a positive impact on improvement of these colonic diseases.

\section{REFERENCES:}

1. Khayyat Y.and Attar S.( 2015)Vitamin D Deficiency in Patients With Irritable Bowel Syndrome: Does It Exist?. Oman Med J.;30:115-118.

2. http://emedicine.medscape.com/article/1790 37-overview , Inflammatory Bowel Disease, 2016

3. Attar S. and Siddiqui A. 2013 Vitamin d deficiency in patients with systemic lupus erythematosus. Oman Med J.;28(1):42-47.

4. Atkinson W, Sheldon TA, Shaath N, Whorwell PJ. (2004). Food elimination based on $\mathrm{IgG}$ antibodies in irritable bowel syndrome: Gut;53(10):1459-1464.

5. Ardesia M, Ferlazzo G, Fries W.( 2015 ). Vitamin D and Inflammatory Bowel Disease. Biomed Res Int.:1-17

6. Drossman DA. (2016). Functional gastrointestinal disorders: history, pathophysiology, clinical features and Rome IV. Gastroenterology. ;150 (6):12621279.

7. National Institutes of Health $(\mathrm{NIH})($ 2020).Vitamin D fact sheet for health professionals. Strengthening Knowledge and Understanding of Dietary Supplements.

8. Fletcher, Sheldon C. Cooper, Subrata Ghosh and Martin Hewison.(2019) The Role of Vitamin D in Inflammatory Bowel Disease: Mechanism to Management. Nutrients.; 11: 10-19 
9. Daryani, T-Vakili, Fereshtehnejad.( 2012). Gender Role in Irritable Bowel Syndrome: A Comparison of Irritable Bowel Syndrome Module (ROME III) Between Male and Female Patient. Journal of neurogastroenterology and motility . 18(1): 70-77

10. Caviezel, D.; Maissen, S.; Niess, J.H.; Kiss, C.; Hruz, P.( 2017). High Prevalence of Vitamin D Deficiency among Patients with Inflammatory Bowel Disease. Inflamm. Intest. Dis., 2, 200-210.

11. Matsuoka K., Taku Kobayashi, Fumiaki Ueno, Toshiyuki Matsui, Fumihito Hirai, et al. (2018). Evidence-based clinical practice guidelines for inflammatory bowel disease. J Gastroenterol 53:305-353.

12. Kopylov U, Rosenfeld G, Bressler B, Seidman E.( 2014). Clinical utility of fecal biomarkers for the diagnosis and management of inflammatory bowel disease. Inflamm Bowel Dis;20:742-756.

13. Bressler B, Panaccione R, Richard N Fedorak, and Ernest G Seidman(2015). Clinicians' guide to the use of fecal calprotectin to identify and monitor disease activity in inflammatory bowel disease Can J Gastroenterol Hepatol; 29(7): 369-372.

14. Cho JH. Inflammatory bowel disease (2008). Genetic and epidemiologic considerations. World J Gastroentero; 14:338-47.

15. Zhao, Yunfeng Wang, Qing Gu, Zhiquan Du, Weichang Chen. (2019). The association between serum vitamin D and inflammatory bowel disease. Medicine 98:18.

16. Schäffler H, Herlemann DP, Klinitzke $P$, Berlin P, Kreikemeyer B, Jaster R, et al.( 2018). Vitamin D administration leads to a shift of the intestinal bacterial composition in Crohn's disease patients, but not in healthy controls. J Dig Dis.;19(4):225-34.

17. Castro FD, Magalhães J, Carvalho PB, Moreira MJ, Mota P, Cotter J (2015). Lower levels of vitamin D correlate with clinical disease activity and quality of life in inflammatory bowel disease. Arq Gastroenterol;52:260-265.

18. Vojinovic Jelena, Angela Tincani, Alberto Sulli, Stefano Soldano. (2017). European multicentre pilot survey to assess vitamin D status in rheumatoid arthritis patients and early development of a new Patient Reported Outcome questionnaire (D-PRO). Autoimmunity Reviews 16 548-554.

19. Abbasnezhad, R. Amani,E. Hajiani, P. Alavinejad, B. Cheraghian \& A. Ghadiri. (2016). Effect of vitamin D on gastrointestinal symptoms and healthrelated quality of life in irritable bowel syndrome patients: a randomized doubleblind clinical trial. Neurogastroenterol Motil 28, 1533-1544

20. Branco J.C. · Cardoso M.F. - Anapaz V. · Lourenço L.C. Oliveira A.M. Rodrigues C.G. - Santos L. (2019). Reis J.A. Vitamin D Deficiency in a Portuguese Cohort of Patients with Inflammatory Bowel Disease: Prevalence and Relation to Disease Activity. GE Port J Gastroenterol; 26:155-162

21. López-Muñoz P, Beltrán B, Sáez-González E, Alba A, Pilar Nos and Marisa Iborra(2019). Influence of Vitamin D Deficiency on Inflammatory Markers and Clinical Disease Activity in IBD Patients. Nutrients, 11, 1059

22. Lorenzo B., Henschel C, Everson' Isadora' Braggio' Sueli ' Clarice (2018). Deficiency of vitamin D and its relation with clinical and laboratory activity of inflammatory bowel diseases. J. Coloproctol.:38. 
تقييم فيتامين (د) في أمراض القولون (مرض القولون العصبي و أمراض التهاب الأمعاُء المزمنة)

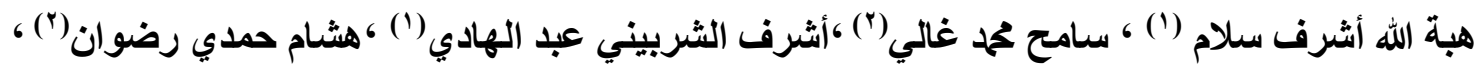

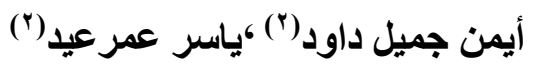

$$
\begin{aligned}
& \text { (') قسم الباطنة العامة . المركز القومي للبحوث }
\end{aligned}
$$

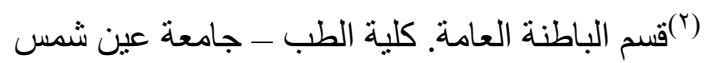

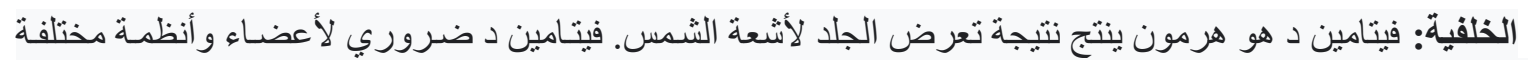

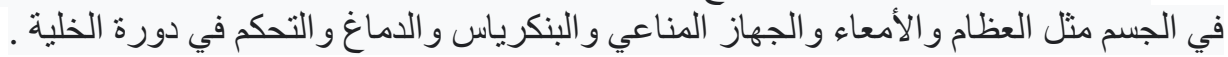

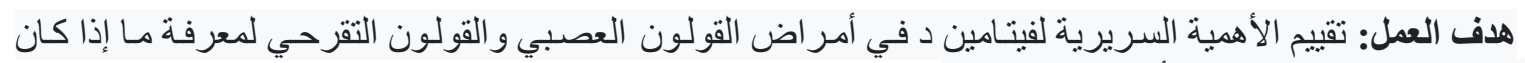

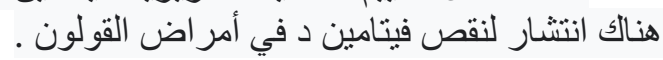

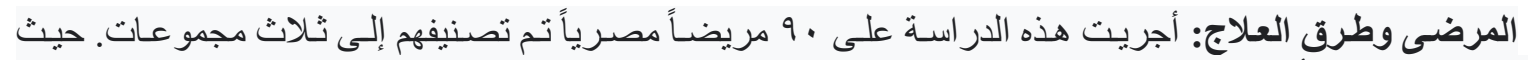

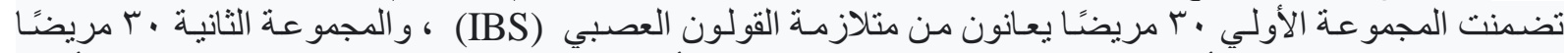

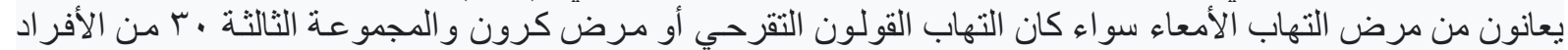
الأصحاء الذين تم أخذهم كمجمو عة تحكم . لأنماء

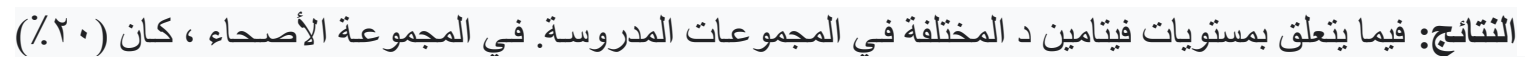

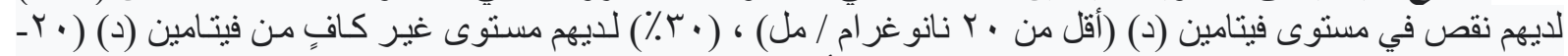

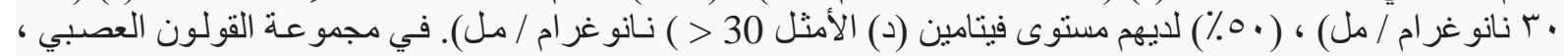

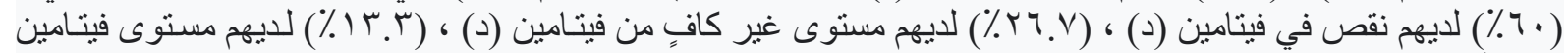

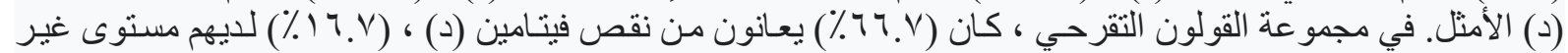

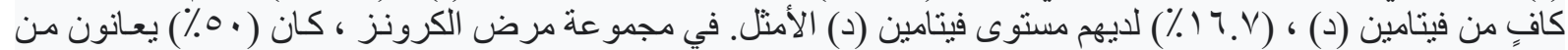

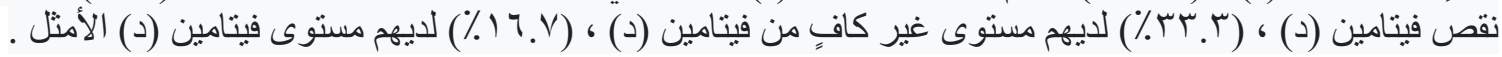

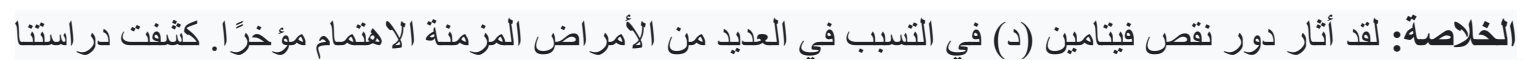

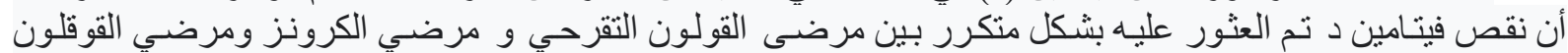
العصبي أكثر من الأصحاء. وبالتالي ، فإن وصفة فيتامين د لهؤلاء المرضى قد تساعد في تحسين أمر اض القون لون لون هذه . 